\title{
The Pyruvate Carboxylase of Verticillium albo-atrum
}

\author{
By R. E. HARTMAN \\ Department of Biology, St Bonaventure University, St Bonaventure, \\ New York, 14778, U.S.A. \\ AND N. T. KEEN \\ Department of Plant Pathology, University of California, \\ Riverside, 92502, U.S.A.
}

(Received 17 April 1973; revised 8 October 1973)

\begin{abstract}
SUMMARY
The pyruvate carboxylase of Verticillium albo-atrum had a $\mathrm{pH}$ optimum of $7 \cdot 8$ and a specific requirement for ATP. At the optimum $\mathrm{pH}$, magnesium ions were required for maximum activity, while at $\mathrm{pH} 6.8$ manganese was more effective than magnesium. Potassium was stimulatory while sodium was ineffective. Avidin and $p$-chloromercuribenzoate strongly inhibited the enzyme while biotin and dithiothreitol, respectively, reversed the effect of the inhibitors. Aspartate and oxalacetate were inhibitory while acetyl-CoA and $\mathrm{CoA}$ reversed the inhibition by aspartate. These cofactors were ineffective in the absence of aspartate. None of the tested metabolic intermediates was stimulatory to pyruvate carboxylase activity while $\mathrm{NADP}^{+}$and 2,3-diphosphoglycerate were the most effective inhibitors $(75 \%)$ at a concentration of $6.7 \mathrm{~mm}$. Levels of pyruvate carboxylase in cells grown on glucose, acetate, malate, xylose, glycerol or aspartate differed only slightly. The data indicated that the physiological role of pyruvate carboxylase in $V$. albo-atrum is the anaplerotic biosynthesis of $\mathrm{C}_{4}$ Krebs-cycle intermediates from pyruvate.
\end{abstract}

\section{INTRODUCTION}

Carbon dioxide was required for growth of Verticillium albo-atrum on glucose or glycerol but not on acetate or succinate (Hartman, Keen \& Long, 1972). Since we also found that the $\mathrm{CO}_{2}$ was used largely in the synthesis of aspartate, glutamate and nitrogen bases, it was hypothesized that anaplerotic biosynthesis of $\mathrm{C}_{4}$ Krebs-cycle intermediates was an important role for $\mathrm{CO}_{2}$ in the physiology of $V$. albo-atrum. The anaplerotic $\mathrm{CO}_{2}$ fixation enzymes pyruvate carboxylase (EC. 6.4.I.I) and phosphoenolpyruvate carboxykinase (EC. 4.I.I.32) were shown to occur in V.albo-atrum (Hartman \& Keen, I973). This report describes studies to determine the properties of pyruvate carboxylase and the effect of various carbohydrates in the growth medium on the activity of this enzyme in V.alboatrum cells.

\section{METHODS}

Preparation of pyruvate carboxylase. Verticillium albo-atrum, strain v3H (ATCC26289), was grown and cells disrupted as described previously (Hartman \& Keen, 1973). Briefly, yeast-phase cells were suspended in the phosphate-breakage buffer, $\mathrm{pH} 6.6$, disrupted in a Bronwill MSK homogenizer, and the supernant from centrifugation for $10 \mathrm{~min}$ at $34000 \mathrm{~g}$ was the source of the enzyme. Dialysis, centrifugation, and fractionation were carried out at 3 to $5{ }^{\circ} \mathrm{C}$. The supernatant ( $\mathrm{I} O \mathrm{ml}$ ) was combined with $2 \mathrm{ml}$ of the phosphate-breakage buffer containing 
Table I. Effect of $p H$ on the activity of pyruvate carboxylase from Verticillium albo-atrum

Reaction mixture ( $\mu \mathrm{mol})$ : tris, 100 : pyruvic acid, Io; ATP, 5 ; biotin, $4 \times 10^{-5} ; \mathrm{KCl}, \mathrm{I00} ; \mathrm{NaHCO}_{3}$, IO; $\mathrm{MgSO}_{4}, 3 ; \mathrm{NaH}^{14} \mathrm{CO}_{3}, 5 \mu \mathrm{Ci}$; protein, $0.2 \mathrm{mg}$; total volume, $\mathrm{I} \cdot 5 \mathrm{ml}$.

$\begin{array}{cc}\mathrm{pH} & \begin{array}{r}\text { Radioactivity incorporated } \\ \text { (c.p.m. } 0.5 \mathrm{ml} \text { ) }\end{array} \\ 7 \cdot \mathrm{I} & 3308 \\ 7 \cdot 5 & 6078 \\ 7 \cdot 8 & 6863 \\ 8 \cdot \mathrm{I} & 5679 \\ 8 \cdot 4 & 2780\end{array}$

$240 \mu \mathrm{mol}$ of oxalacetate and incubated for $30 \mathrm{~min}$ at $23^{\circ} \mathrm{C}$. Ammonium sulphate $(2 \cdot 8 \mathrm{I} \mathrm{g})$ was added slowly to Io $\mathrm{ml}$ of the cooled solution $\left(3{ }^{\circ} \mathrm{C}\right)$ to achieve approximately $45 \%$ saturation $\left(23^{\circ} \mathrm{C}\right)$. The precipitate was removed by centrifugation and $\mathrm{I} \cdot 25 \mathrm{~g}$ of ammonium sulphate was added to achieve $65 \%$ saturation $\left(23^{\circ} \mathrm{C}\right)$. The precipitate was removed by centrifugation and suspended in $4 \mathrm{ml}$ of a solution containing $0 . \mathrm{I}$ M-potassium phosphate and $0.025 \mathrm{M}$ oxalacetate, $\mathrm{pH} 6 \cdot 6$, and then dialysed against $0 . \mathrm{I}$ M-potassium phosphate buffer, $\mathrm{pH} 6.6$, with four hourly changes of $15 \times$ volume. The enzyme preparation represented a fourfold purification over the oxalacetate-preincubated and dialysed cell extract. It generally contained 2 to $3 \mathrm{mg}$ protein $/ \mathrm{ml}$ and fixed 0.04 to $0.06 \mu \mathrm{mol}$ carbon $/ \mathrm{min} / \mathrm{mg}$ protein. The specific activity was determined at $\mathrm{pH} 7.8$ under the conditions shown in Table $\mathrm{I}$. The total carbonate present was estimated to be I I $\mu \mathrm{mol}$, based on the $10 \mu \mathrm{mol}$ added and the presence of about I $\mu \mathrm{mol}$ of dissolved carbonate (Feir \& Suzuki, I969).

Assay methods. Protein was estimated by the method of Lowry, Rosebrough, Farr \& Randall (195I) with bovine serum albumin as the standard.

The procedure for measuring the fixation of $\mathrm{NaH}^{14} \mathrm{CO}_{3}$ has been described in detail (Hartman \& Keen, I973). The specific activity of the $\mathrm{NaH}^{14} \mathrm{CO}_{3}$ was $50 \mathrm{mCi} / \mathrm{mm}$. A Io min incubation period was used to determine enzyme activity; enzyme activity had previously been shown to be linear with respect to time for the first Io min.

\section{RESULTS}

The optimal $\mathrm{pH}$ for the activity of pyruvate carboxylase was approximately 7.8 (Table $\mathrm{I}$ ). Inosine- 5 -triphosphate, guanosine- $5^{\prime}$-triphosphate, or uridine- $5^{\prime}$-triphosphate was not able to replace adenosine-5'-triphosphate in the reaction mixture at $\mathrm{pH} 7 \cdot 8$. When the divalent cations $\mathrm{MgSO}_{4}, \mathrm{MnSO}_{4}, \mathrm{CoCl}_{2}, \mathrm{ZnSO}_{4}, \mathrm{CaCl}_{2}$ or $\mathrm{FeSO}_{4}$ were used at $2 \mu \mathrm{mol}$ in the reaction mixture at $\mathrm{pH} 7 \cdot 8$, only $\mathrm{MgSO}_{4}$ supported a high level of enzyme activity. Raising the $\mathrm{MgSO}_{4}$ concentrations to $3 \mu \mathrm{mol}$ increased enzyme activity by $50 \%$.

When biotin was omitted from this reaction mixture there was no decrease in fixation. The importance of biotin in the reaction, however, was demonstrated by the complete inhibition of enzyme activity which resulted when biotin was replaced with I unit of avidin and by the reversal of this inhibition by the inclusion of $\mathrm{I} \mu \mathrm{g}$ biotin.

A relationship was found between $\mathrm{pH}$ and the relative effectiveness of $\mathrm{Mg}^{2+}$ and $\mathrm{Mn}^{2+}$ in supporting carboxylase activity. As the $\mathrm{pH}$ was decreased from $7 \cdot 8$ to 6.8 the relative effectiveness of $\mathrm{Mg}^{2+}$ decreased and that of $\mathrm{Mn}^{2+}$ increased, so that at $\mathrm{pH} 6.8 \mathrm{Mn}^{2+}$ was more effective than $\mathrm{Mg}^{2+}$ (Table 2 ). Activity was maximal with $\mathrm{Mg}^{2+}$ at $\mathrm{pH} 7 \cdot 8$. 
Table 2. Effect of $p H$, magnesium and manganese on pyruvate carboxylase activity from Verticillium albo-atrum

Reaction mixture $(\mu \mathrm{mol}):$ tris, 100 ; pyruvic acid, 10 ; ATP, 5 ; biotin, $4 \times 10^{-5} ; \mathrm{KCl}, 100$; cation, $2 ; \mathrm{KHCO}_{3}, \mathrm{I}$; $\mathrm{NaH}^{14} \mathrm{CO}_{3}, 5 \mu \mathrm{Ci}$; protein, $0.2 \mathrm{mg}$; total volume, $\mathrm{I} \cdot 5 \mathrm{ml}$.

$\begin{array}{ccc}\text { Cacion added } & \begin{array}{c}\mathrm{pH} \text { of } \\ \text { reaction mixture }\end{array} & \begin{array}{r}\text { Radioactivity incorporated } \\ \text { (c.p.m., } 0.5 \mathrm{ml} \text { ) }\end{array} \\ \text { None } & 7 \cdot 9 & 248 \\ \mathrm{MgSO}_{4} & 7 \cdot 9 & 10888 \\ \mathrm{MnSO}_{4} & 7 \cdot 9 & 1078 \\ \mathrm{MgSO}_{4} & 7 \cdot 2 & 4442 \\ \mathrm{MnSO}_{4} & 7 \cdot 2 & 3888 \\ \mathrm{MgSO}_{4} & 6 \cdot 8 & 1702 \\ \mathrm{MnSO}_{4} & 6 \cdot 8 & 3823\end{array}$

Table 3. Effect of sodium, potassium and bicarbonate on pyruvate carboxylase activity

Reaction mixture $(\mu \mathrm{mol})$ : tris, Ioo; pyruvic acid, Io; ATP, 5 ; biotin, $4 \times 10^{-5}$; $\mathrm{MgSO}_{4}, 3 ; \mathrm{NaH}^{14} \mathrm{CO}_{3}, 5 \mu \mathrm{Ci}$; protein, $0.2 \mathrm{mg}$; total volume, $1.5 \mathrm{ml} ; \mathrm{pH} 8.0$.

Substance(s) added $(\mu \mathrm{mol})$

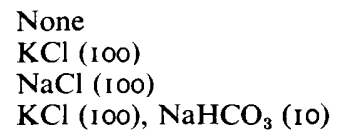

Radioactivity incorporated (c.p.m. $0.5 \mathrm{ml}$ )
16886
29303
15998
11359

Table 4. Effect of acetyl-CoA and CoA on pyruvate carboxylase

Reaction mixture $(\mu \mathrm{mol})$ : tris, I00; pyruvate, 10 ; ATP, 5 ; biotin, $4 \times 10^{-5} ; \mathrm{KCl}, 100$; $\mathrm{MgSO}_{4}, 3 ; \mathrm{KHCO}_{3}, \mathrm{I0} ; \mathrm{NaH}^{14} \mathrm{CO}_{3}, 5 \mu \mathrm{Ci}$; protein, $0.3 \mathrm{mg}$; total volume, $\mathrm{I} \cdot 5 \mathrm{ml} ; \mathrm{pH} 7.9$.

$\begin{array}{cccc}\begin{array}{c}\text { Substance(s) added } \\ (\mu \mathrm{mol})\end{array} & \begin{array}{c}\text { Radioactivity } \\ \text { incorporated } \\ (\%)\end{array} & \begin{array}{c}\text { Substance(s) added } \\ (\mu \mathrm{mol})\end{array} & \begin{array}{c}\text { Radioactivity } \\ \text { incorporated } \\ (\%)\end{array} \\ \text { None } & 100^{*} & \text { Aspartate + CoA } & 98 \\ \text { CoASAc }(0.5) & 99 & \text { Oxalacetate }(7.5) & 30 \\ \text { CoA }(0.5) & 96 & + \text { CoASAc } & 34 \\ \text { Aspartate }(7.5) & 27 & + \text { CoA } & 34 \\ \text { + CoASAc } & 93 & & \\ * \text { The radioactivity incorporated here was } 13675 \text { c.p.m. } / 0.5 \mathrm{ml} . & \end{array}$

At the concentration tested, potassium ions increased enzyme activity (Table 3) but sodium ions did not.

The addition of dithiothreitol $(20 \mu \mathrm{mol})$ to the optimum reaction mixture did not enhance pyruvate carboxylase activity. The importance of free thiol groups for activity, however, was demonstrated by the complete inhibition that resulted when the enzyme was incubated in the reaction mixture containing $p$-chloromercuribenzoate $(0.015 \mu \mathrm{mol})$ for $3 \mathrm{~min}$ before the addition of $\mathrm{NaH}^{14} \mathrm{CO}_{3}$. This inhibition was partially reversed $(40 \%)$ when dithiothreitol $(20 \mu \mathrm{mol})$ was added to the reaction mixture containing the inactivated enzyme $2 \mathrm{~min}$ before the $\mathrm{NaH}^{14} \mathrm{CO}_{3}$.

Neither coenzyme A (CoA) nor acetyl coenzyme A (CoASAc) enhanced enzyme activity when added to the reaction mixture (Table 4 ). Both aspartate and oxalacetate inhibited the reaction approximately $28 \%$ at $5.0 \mathrm{~mm}$. The basis for inhibition by these compounds must 
Table 5. Effect of metabolic intermediates on pyruvate carboxylase

\begin{tabular}{|c|c|c|c|}
\hline $\begin{array}{l}\text { Compound added* } \\
\text { (IO } \mu \mathrm{mol})\end{array}$ & $\begin{array}{l}\text { Inhibition } ! \\
(\%)\end{array}$ & $\begin{array}{l}\text { Compound added* } \\
\text { (10 } \mu \mathrm{mol})\end{array}$ & $\begin{array}{l}\text { Inhibition } \dagger \\
(\%)\end{array}$ \\
\hline Control† & 0 & $\mathrm{NADP}^{+}$ & 74 \\
\hline Malate & 18 & $\mathrm{NADP}^{+}+\mathrm{CoASAc}(0.5 \mu \mathrm{mol})$ & 66 \\
\hline Succinate & I 5 & Glycerol & 0 \\
\hline Fumarate & 14 & DL-Glycerol-3-P & 27 \\
\hline Citrate & I4 & DL-Glyceraldehyde-3-P & 32 \\
\hline DL-Isocitrate & I 5 & Glycerate-3-P & 19 \\
\hline 2-Oxoglutaric acid & 18 & Glycerate-2-P & 29 \\
\hline Glutamate & 4 & Glycerate-2,3-P & 79 \\
\hline Alanine & 7 & Fructose-6-P & 26 \\
\hline$\beta$-NADH & 35 & Fructose-1,6- $\mathrm{P}_{2}$ & 39 \\
\hline NADPH & 44 & Glucose-I-P & IO \\
\hline$\beta$-NAD ${ }^{+}$ & 47 & Glucose-6-P & 17 \\
\hline
\end{tabular}

* Reaction mixture ( $\mu \mathrm{mol})$ : tris, I00; pyruvate, 10 ; ATP, 5 ; biotin, $4 \times 10^{-5} ; \mathrm{KCl}, 100 ; \mathrm{MgSO}_{4}, 3$; $\mathrm{KHCO}_{3}, 10 ; \mathrm{KH}^{14} \mathrm{CO}_{3}, 5 \mu \mathrm{Ci}$; protein, $0.25 \mathrm{mg}$; total volume, $\mathrm{I} \cdot 5 \mathrm{ml} ; \mathrm{pH} 7 \cdot 9$. Where DL compounds were used, $20 \mu \mathrm{mol}$ was added.

$\dagger$ The control value ( $0 \%$ inhibition) was the radioactivity obtained in reaction mixtures in the absence of the added intermediates. The radioactivity fixed by controls averaged about 12500 c.p.m. $/ 0.5 \mathrm{ml}$ in the several experiments from which these data were obtained.

Table 6. Effect of carbon source on the synthesis of pyruvate carboxylase

Cells were grown in the carbohydrate $(5 \mathrm{~g} / \mathrm{l})$-ammonium nitrate $(2.43 \mathrm{~g} / \mathrm{l})$-biotin medium, $\mathrm{pH} 6.3$, (Hartman, Keen \& Long, 1972). The enzyme preparation was an oxalacetate-preincubated, dialysed cell extract. The composition of the reaction mixture was as described in Table $\mathbf{1}, \mathrm{pH} 7 \cdot 8$.

$\begin{array}{cr}\begin{array}{c}\text { Carbon source } \\ (0.5 \%)\end{array} & \begin{array}{r}\text { Specific radi } \\ \text { incorpor } \\ \left(\mathrm{I} 0^{3} \mathrm{c.p} . \mathrm{m} . / \mathrm{m}\right.\end{array} \\ \begin{array}{cc}\text { Expt A } \\ \text { Glucose }\end{array} \\ \text { Pyruvate } & 24 \\ \text { Expt B } & 30 \\ \text { Glucose } & \\ \text { Acetate } & 20 \\ \text { Malate } & 20 \\ \text { Xylose } & 13 \\ \text { Glycerol } & 18 \\ \text { Expt C } & 18 \\ \text { Glucose } & \\ \text { Aspartate+glucose }(0.02 \%) & 37 \\ & 25\end{array}$

differ because both CoA and CoASAc at a level of $5.0 \mathrm{~mm}$ reversed the inhibition by aspartate but had little effect on the inhibition by oxalacetate (Table 4). Perhaps the latter was simply the result of product inhibition.

The effect of various metabolic intermediates on enzyme activity is illustrated in Table 5 . Among the glycolytic pathway intermediates, 2,3-diphosphoglyceric acid was the most inhibitory (79\%) while fructose-I,6-diphosphate inhibited the enzyme by $39 \%$. The nicotinamide cofactors tested were all significantly inhibitory, $\mathrm{NADP}^{+}$being the most effective $(74 \%)$. Acetyl-CoA only slightly reversed the inhibitory effect of NADP ${ }^{+}$.

Growth of the cells in media with various single carbon sources did not result in levels of pyruvate carboxylase activity that were significantly different from those in cells grown on glucose (Table 6). 


\section{DISCUSSION}

The physiological role of the Verticillium albo-atrum pyruvate carboxylase appears to be the anaplerotic conversion of pyruvate to oxalacetate, since aspartate inhibits the enzyme and this inhibition is reversed by CoASAc. Such observations have generally been interpreted as denoting the importance of the enzyme in modulating levels of Krebs-cycle intermediates (Utter \& Scrutton, I969). The properties of the $V$. albo-atrum pyruvate carboxylase are similar to those of the enzyme from other sources with respect to $\mathrm{pH}$ range, the requirement for a divalent ion and a monovalent ion, and the importance of biotin and free sulphydryl groups for enzyme activity (Scrutton \& Young, 1970).

Activity of the Verticillium albo-atrum pyruvate carboxylase does not appear to be modulated by repression since no significant changes in activity were observed by growing the cells on various carbon sources. This is similar to observations with other microbial systems. The enzyme activity showed little change when Bacillus licheniformis was grown on glucose, malate, glycerol, peptone-yeast extract, or pyruvate (Renner \& Bernlohr, 1972). Rhodotorula glutinis also had approximately the same enzyme activity whether grown on glucose, pyruvate, malate, aspartate, or acetate (Ruiz-Amil et al. 1965). Activity in Rhodopseudomonas spheroides was the same on acetate, glucose, pyruvate, malate, or lactate in the dark; in light, however, the activity of pyruvate carboxylase was doubled on pyruvate or lactate as compared to glucose (Payne \& Morris, 1969).

\section{REFERENCES}

Feir, H. A. \& SuzUki, I. (1969). Pyruvate carboxylase of Aspergillus niger: kinetic study of a biotincontaining carboxylase. Canadian Journal of Biochemistry 47, 697-710.

Hartman, R. E. \& Keen, N. T. (1973). Enzymes capable of anaplerotic carbon dioxide fixation in Verticillium albo-atrum. Phytopathology 63, 947-953.

Hartman, R. E., Keen, N. T. \& Long, M. (1972). Carbon dioxide fixation by Verticillium albo-atrum. Journal of General Microbiology 73, 29-34.

Lowry, O. H., Rosebrough, N. J., Farr, A. L. \& Randall, R. J. (195I). Protein measurements with the Folin phenol reagent. Journal of Biological Chemistry 193, 265-275.

PAYNe, J. \& MORRIS, J. G. (1969). Pyruvate carboxylase in Rhodopseudomonas spheroides. Journal of General Microbiology 59, 97-Ior.

RENNER, E. D. \& BERNLOHR, R. W. (1972). Characterization and regulation of pyruvate carboxylase of Bacillus licheniformis. Journal of Bacteriology 109, 764-772.

Ruiz-Amil, M., de Torrontegui, G., Palacian, E., Cataline, L. \& Losada, M. (I965). Properties and function of yeast pyruvate carboxylase. Journal of Biological Chemistry 240, 3485-3492.

Scrutron, M. C. \& Young, M. R. (1970). Pyruvate carboxylase. In The Enzymes, vol. 6, 3rd edn, pp. 1-35. Edited by P. D. Boyer. New York: Academic Press.

Utter, M. F. \& Scrutton, M. C. (1969). Pyruvate carboxylase. Current Topics in Cellular Regulation I, 253-296. 